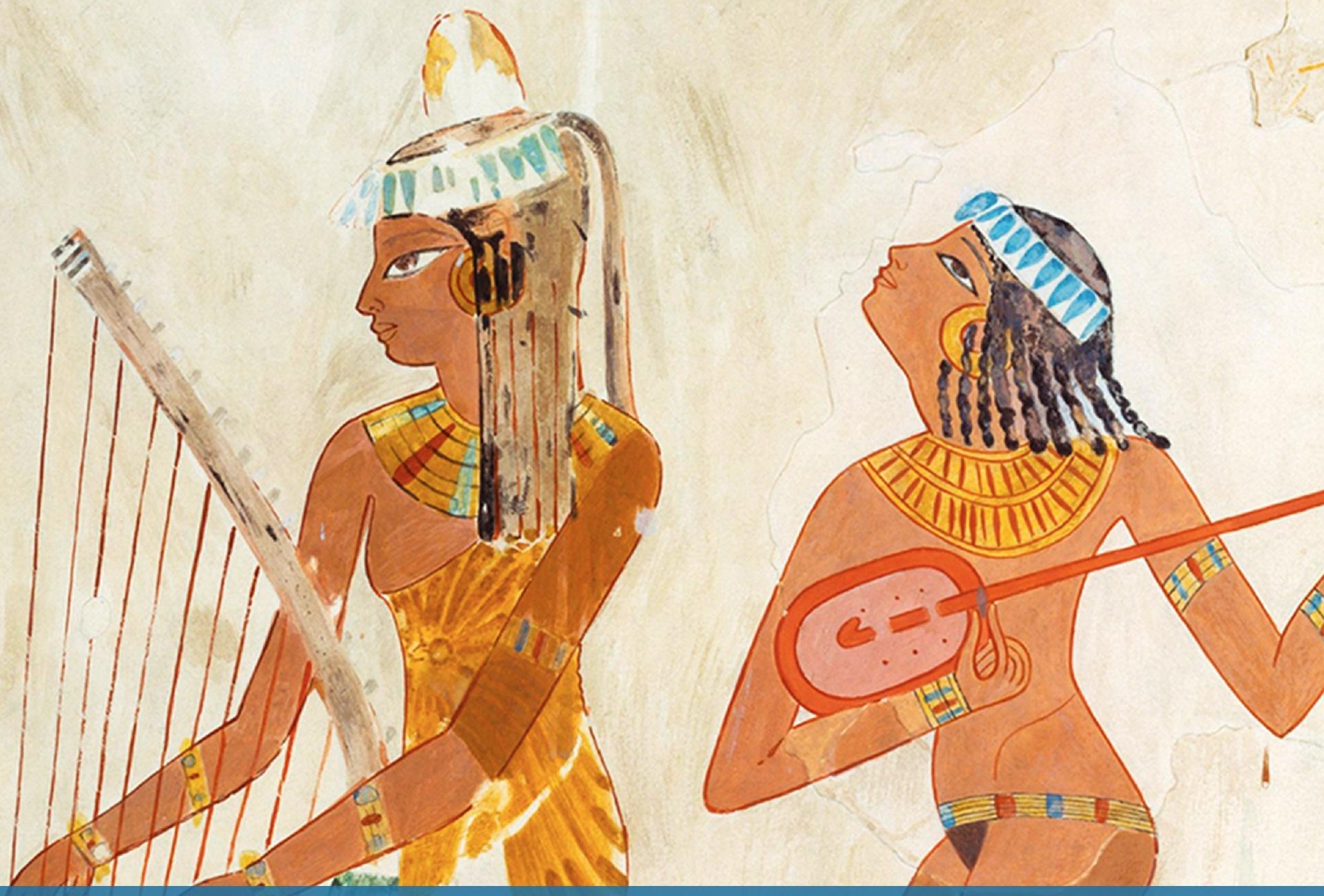

Revista digital de ciencia y Didáctica de la Historia

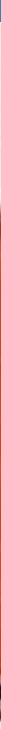




\section{Panta Rei \\ Revista Digital de Ciencia \\ y Didáctica de la Historia}

\section{9}

Revista anual

Fecha de inicio: 1995

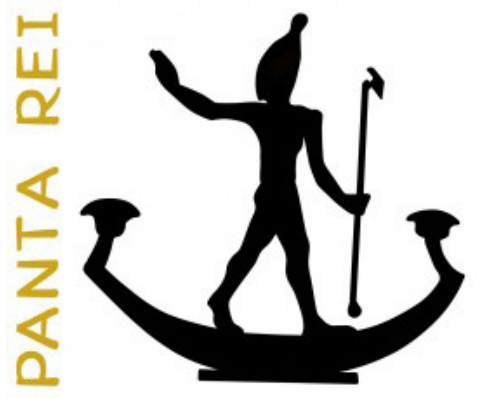

Revista Panta Rei. pantarei@um.es

Edita:

Centro de Estudios del Próximo Oriente y la

Antigüedad Tardía - CEPOAT

Edificio Universitario Saavedra Fajardo.

Universidad de Murcia

C/ Actor Isidoro Máiquez, 9

30007 - MURCIA - ESPAÑA

Teléfono: (+34) 868883890

cepoat@um.es

Web: www.um.es/cepoat/pantarei

Edición 2019

ISSNe: 2386-8864

Responsable de la presente edición: Consejo Editorial Panta Rei.

UNIVERSIDAD DE MURCIA centro de estudios del próximo oriente y la antigüedad tardía

En Portada: Fragmento de pintura de la tumba de Djeserkareseneb (TT38), Tebas. (fotografía del Metropolitan Museum).

Responsables de los textos: Sus autores.

ISSN: 1136-2464

Depósito legal: MU-966-1995 


\section{CONSEJO DE REDACCIÓN}

\section{Coordinador editorial}

Egea Vivancos, Alejandro

[Didáctica de las Ciencias Sociales, UMU]

\section{Editores}

Jiménez Vialás, Helena

[UMU]

López Muñoz, Dámaris

[UJA]

Meseguer Gil, Antonio José

[CEPOAT, UNED]

Sáez Giménez, David Omar

[CEPOAT, UMU]

Sánchez Mondéjar, Celso Miguel

[Patrimonio Inteligente]

\section{Secretaria}

Arias Ferrer, Laura

[Didáctica de las Ciencias Sociales, UMU]

\section{Responsable informático}

Martínez García, José Javier

[CEPOAT, UMU]

\section{Traducción y corrección lingüística}

Martínez Martínez, Cristina

[Sociedad Española de Lenguas Modernas]

Albaladejo Albaladejo, Sara

[ISEN, UMU]

\section{CONSEJO ASESOR}

Adroher Auroux, Andrés María [Arqueología, Universidad de Granada]

Albero Muñoz, M. ${ }^{a}$ del Mar [Historia del Arte, Universidad de Murcia]

Alia Miranda, Francisco [Historia Contemporánea, UCLM]

Arciniega García, Luis [Historia del Arte, Universidad de Valencia]

Barrio Barrio, Juan Antonio [Historia Medieval, Universidad de Alicante]

Castellano i Solé, Núria [Egiptología, Schola Didàctica Activa S.L.]
Chapman, Arthur [History Education, University College of London, Reino Unido]

Cid López, Rosa María [Historia Antigua, Universidad de Oviedo]

Cobacho López, Ángel [Derecho, Universidad de Murcia]

Cuenca López, José María [Didáctica de las Ciencias Sociales, Universidad de Huelva]

Egea Bruno, Pedro M. ${ }^{a}$ [Historia Contemporánea, Universidad de Murcia]

Feijoo Martínez, Santiago [Arqueología, Consorcio Ciudad Monumental de Mérida]

García Atienzar, Gabriel [Prehistoria, Universidad de Alicante]

Ginestí Rosell, Anna [Filología Clásica, Katholische Universität Eichstätt-Ingolstadt]

González Monfort, Neus [Didáctica de las Ciencias Sociales, Universidad Autónoma de Barcelona]

González Soutelo, Silvia [Arqueología, Universidad de Vigo]

Haber Uriarte, María [Prehistoria, Universidad de Murcia]

Hernández de la Fuente, David [Historia Antigua, Universidad Complutense]

Hutson, Scott R. [Anthropology, University of Kentucky, EE UU]

Igual Luis, David [Historia Medieval, UCLM]

Irigoyen López, Antonio [Historia Moderna, Universidad de Murcia]

Jover Maestre, Francisco Javier [Prehistoria, Universidad de Alicante]

Mahony, Simon [Digital Humanities, University College of London, Reino Unido]

Marsilla de Pascual, Francisco Reyes [Técnicas historiográficas, Universidad de Murcia]

Martínez-Burgos García, Palma [Historia del Arte, UCLM]

Mathis, Christian [Didaktik der Geschichte, PH Zürich]

Miralles Maldonado, José Carlos [Filología Clásica, Universidad de Murcia]

Molina Gómez, José Antonio [Historia Antigua, Universidad de Murcia]

Mónica Ghirardi [Historia Moderna, Universidad Nacional de Córdoba, Argentina]

Navarro Espinach, Germán [Historia Medieval, Universidad de Zaragoza]

Noguera Celdrán, José Miguel [Arqueología, Universidad de Murcia]

Ortiz Heras, Manuel [Historia Contemporánea, UCLM]

Panzram, Sabine [Historia Antigua, Universität Hamburg]

Pérez Molina, Miguel Emilio [Filología Clásica, Universidad de Murcia]

Prados Martínez, Fernando [Arqueología, Universidad de Alicante]

Sánchez Ibáñez, Raquel [Didáctica de las Ciencias Sociales, Universidad de Murcia]

Sancho Gómez, Miguel Pablo [Educación, UCAM]

Victoria Moreno, Diego [Historia Contemporánea, UNED]

Vilar García, María José [Historia Contemporánea, Universidad de Murcia]

Vivas Sainz, Inmaculada [Historia del Arte, UNED]

Zamora López, José Ángel [Próximo Oriente Antiguo, CCHS-CSIC] 



\section{Índice}

\section{Artículos}

La imagen de la Prehistoria en el cine y los géneros del cine prehistórico. Un mundo de hombres mono, bikinis y dinosaurios.

Alberto Lombo Montañés.

Trabajo y roles de género durante la Prehistoria. Un estudio sobre su percepción en el alumnado de Historia.

María Pastor Quiles y Daniel Mateo Corredor.

Memoria cultural en el Egipto Faraónico. Algunas reflexiones sobre su origen, función y pervivencia histórica.

Antonio Pérez Largacha.

La representación de la danza dentro de las escenas de banquete de las tumbas tebanas privadas de la XVIII dinastía egipcia.

Miriam Bueno Guardia.

La "Sala del Fresco" de Micenas. Revisión de las interpretaciones del programa iconográfico y nueva lectura en relación a los espacios.

Pelayo Huerta Segovia.

Las advertencias de Quilón y Solón sobre la tiranía de Pisístrato.

Unai Iriarte.

La Virgen de la Leche. Arquetipo de mujer y madre en la pintura del Renacimiento español.

Patricia Castiñeyra Fernández

Innovación didáctica en Historia: un estado de la cuestión en torno a cuatro ejes temáticos.

Diego Luna Delgado.

\section{Reseñas}

Foster, B. R. (2016), The Age of Agade. Inventing empire in ancient Mesopotamia, Londres y Nueva York: Routledge, 438 págs.

Juan Álvarez García.

Alviz Fernández, M. y Hernández de la Fuente, D. (Eds.) (2017). De ópos a limes: el concepto de frontera en el mundo antiguo y su recepción. Madrid: Escolar y Mayo editores. 256 págs.

Ethan Yepes de la Hoz.

Clares Clares, M ${ }^{\mathrm{a}}$ E. (2017). Música y noches de moda. Sociedades, cafés y salones domésticos de Murcia en el siglo XIX. Murcia: Universidad de Murcia, Servicio de Publicaciones. 474 págs.

Elena Micó Terol 195

Goñi Zabalegui, A. (2018). Género y sociedad en el Egipto romano. Una Mirada desde las cartas de mujeres. Oviedo: Ediciones de la Universidad de Oviedo. 360 págs.

Alejandra Izquierdo Perales. 199

Normas de publicación/Publishing rules 



\title{
Las advertencias de Quilón y Solón sobre la tiranía de Pisístrato ${ }^{1}$
}

\author{
Chilon and Solon Warnings about Peisistratos' Tyranny
}

\author{
Iriarte, Unai \\ Universidad de Sevilla
}

\author{
Recibido: 19/01/2019
}

Aceptado: 04/04/2019

Para citar este artículo: Iriarte, U. (2019). Las advertencias de Quilón y Solón sobre la tiranía de Pisístrato. Panta Rei. Revista Digital de Ciencia y Didáctica de la Historia, 113-128.

ISSNe: $2386-8864$

DOI: $10.6018 /$ pantarei/2019/06

\section{Resumen}

La manera en la que conformamos una determinada memoria a partir de hechos trágicos de nuestro pasado repercute en el conocimiento que tenemos de dicho pasado. En el presente artículo se pretende dirimir la veracidad de dos episodios a través de los cuales Quilón de Esparta y Solón de Atenas, dos de los Siete Sabios de la antigua Grecia, avisan de las intenciones de Pisístrato en la consecución de su tiranía. Para ello se analizan ambos casos por separado, atendiendo al contexto de las fuentes y su evolución histórica, a fin de entender su plasmación en la historiografía de los siglos $\mathrm{V}$ y IV a. C. El análisis historiográfico de estos dos acontecimientos en sus respectivas fuentes nos permite concluir que ambos avisos eran más literarios que históricos.

\section{Palabras clave}

Memoria, Civilización griega, Interpretación histórica, Historiografía, Historia social.

\begin{abstract}
The way in which we shape a particular memory based on tragic facts of the past has an effect on the knowledge we have of that past. In this article, we aim to discern the reliability of two episodes in which Chilon of Sparta and Solon of Athens, two of the Seven Wise men of ancient Greece, warn about Pisistrato's becoming a tyrant. Hence we analyse both cases separately, paying special attention to the sources and their historical evolution, in order to understand these episodes' presence in the historiography of the 5th and 4th centuries B.C. Historiographical analysis of both stories in their respective sources let us conclude that both warnings were more literary than historical.
\end{abstract}

\section{Keywords}

Memory, Greek civilization, Historical interpretation, Historiography, Social History.

1 El presente trabajo ha contado con la financiación del VI PPIT de la Universidad de Sevilla.

2 Para contactar con el autor: Unai Iriarte. Universidad de Sevilla. uiriarte@us.es. 


\section{Introducción}

La forma en la que se (re)construye el relato histórico es fundamental para anclar una determinada memoria en un pueblo. Además, estudios recientes han demostrado que la memoria social de un grupo concreto depende de las necesidades del mismo. Y, por tanto, esta va variando a lo largo del tiempo adaptándose a según qué necesidades (Forsdyke, 2008). Este hecho hace que cualquier estudio del pasado esté condicionado, a su vez, por el contexto social en el que está inserto el transmisor de dicho pasado. En el caso de la tiranía de los Pisistrátidas, Heródoto es el primer autor que nos traslada una digresión más o menos extensa, ya en la segunda mitad del siglo $V$ a. C., sobre los acontecimientos que condujeron a su instauración en Atenas más de cien años antes, por lo que su estudio resulta fundamental para cualquier intento de aproximación a este período de la historia ateniense. Los ejemplos en los que un pueblo manipula su propio pasado, según pasa el tiempo, son extensos y variados. En el caso de la historiografía antigua, aun son más abundantes en aquellos casos en los que las fuentes aluden a períodos críticos de la historia de sus propias poleis, como cuando se encontraban bajo regímenes tiránicos. En el presente trabajo se pretende abordar, pues, el estudio de dos anécdotas que nos son transmitidas por primera vez bajo democracia (con la interpretación moral particular que ello supone), y que tienen por protagonistas a dos de los siete Sabios de Grecia, quienes intervinieron de una manera sobre todo simbólica en el advenimiento de la primera tiranía de Atenas. Se ha decidido que sean ambas intervenciones las analizadas por varias razones, no sólo por cuestiones de limitación formal de un artículo científico. Ambas situaciones (históricas o no) remiten a los únicos acontecimientos previos a la llegada de Pisístrato que se nos han conservado y que tienen una relación directa con el futuro tirano sin ser este un agente que participe de manera directa. Además, estas dos anécdotas recogen en cierta medida vaticinios, adivinaciones, avisos sobre sucesos que acaban convirtiéndose en realidad. Es decir, en estos dos episodios, con Quilón de Esparta primero y Solón de Atenas después como protagonistas, dos de los siete sabios de Grecia advirtieron y previeron lo qué iba a ocurrir. Se adelantaron a los hechos y, con ello, generaron las dudas actuales presentes entre los historiadores modernos sobre la veracidad histórica de sus presagios. Así pues, el fin de este trabajo es reconocer qué hay de netamente histórico en sus posicionamientos y qué de memoria social o relato construido a posteriori.

\section{Quilón de Esparta: vaticinio desde Olimpia}

La primera referencia "histórica" documentada de Quilón coincide con el inicio de la digresión sobre la tiranía de los Pisistrátidas en Heródoto. Este historiador nos relata su encuentro en Olimpia con Hipócrates, el futuro padre de Pisístrato (I 59.1-3):

AHipócrates, porcierto, que era un simple particular, le había sucedido un notable prodigio cuando asistía a los juegos olímpicos; en efecto, cuando él, personalmente, había ya inmolado las víctimas, los calderos, que estaban ya a punto y que se hallaban repletos de carne y agua, rompieron a hervir sin fuego hasta desbordarse. Entonces el lacedemonio Quilón, que acertó a pasar por allí y vio el prodigio, aconsejó a Hipócrates que, ante todo, no contrajera matrimonio con una mujer prolífica y, como segunda opción, que, si ya la tenía, la repudiara; y, si por casualidad tenía algún hijo, que renunciara a él. Pese a ello, Hipócrates no quiso seguir esos consejos de Quilón y, con el tiempo, tuvo al mencionado Pisístrato.

El estudio de los diferentes pasajes de las Historias de Heródoto puede realizarse desde dos perspectivas distintas, y no necesariamente contrarias. De manera analítica, esto es, atendiendo a las razones por las cuales el de Halicarnaso habría decidido incluir un determinado contenido en su obra, es decir, las motivaciones históricas que le habrían hecho referirse a un acontecimiento 
concreto; y de manera unitaria, o lo que es lo mismo, valorando la importancia literaria que tiene la presencia de un episodio concreto para el conjunto de la obra y de su desarrollo como texto (Lateiner, 1989).

En primer lugar, pues, abordaremos este episodio de Quilón desde un enfoque analítico. Como se puede ver, este pasaje tiene mucho de fantástico. En gran medida por la propia presencia de Quilón en él, un personaje que bien podríamos considerar pseudohistórico y que, en la misma línea que decía Plutarco (Lyc. 1.2) sobre Licurgo, de él "nada absolutamente que no esté sujeto a dudas puede decirse". Gracias a Diógenes Laercio (I 68), quien sigue a Sosícrates, y este, a su vez, al cronista Apolodoro, podemos decir que Quilón se habría convertido en éforo epónimo en Esparta hacia el 556/5 a. C. La referencia explícita por parte de Diógenes Laercio a hasta dos fuentes diferentes para pronunciarse sobre dicho personaje deja patente la falta de seguridad de los diferentes autores al intentar transmitir información sobre Quilón, así como la dificultad existente a la hora de trazar su desarrollo histórico, una problemática no falta de visiones contrapuestas todavía hoy. De hecho, existen dos corrientes historiográficas diferentes respecto al eforado de Quilón. Por un lado están quienes creen (Asheri, Lloyd y Corcella, 2007; Na ssi, 1991; Stibbe, 1985), siguiendo a Diógenes Laercio (I 68), que sí fue éforo en Esparta. Pero, por otro lado, también están los que (Fehling, 1985; Luther, 2002) piensan que se trataría de una invención fruto de una tradición literaria posterior que trataría de equiparar este personaje a Solón y su arcontado.

De dar por cierto el pasaje que nos traslada Heródoto -al margen obviamente de los elementos fantásticos que se suceden, como el hecho de que los calderos se pongan a hervir sin agua-, creemos que esta situación se habría producido en los Juegos de 608 o en los de 604, en los que Quilón no habría tenido más de treinta años (Asheri, Lloyd y Corcella, 2007)3. Aunque también hay otros autores (Stibbe, 1985; Thommen, 1996; 2017) que lo rebajan al 600 a. C. Sea cual sea la fecha, a dicha edad no podía ser reconocido entre los griegos como uno de los Siete Sabios todavía, era demasiado joven. Además, a finales del siglo VII a. C., que es cuando este encuentro habría tenido lugar, todavía no había surgido siquiera la leyenda de los Siete Sabios de Grecia. Diógenes Laercio (I 22), siguiendo a su vez a Demetrio de Falero, señala como inicio de la misma el año 582 a. C., durante el arcontado de Damasio en Atenas, cuando se le empezó dando este título a Tales de Mileto. Y no serían documentados todos los Sabios en su conjunto hasta el siglo IV a. C. (PI. Prot. 343a). Por todo ello, Quilón sería ya considerado como sabio más adelante, y en parte como consecuencia de esta fama es por lo que según la tradición posterior lo nombrarían éforo en Esparta. Existen, de todas maneras, innumerables dificultades a la hora de establecer la historicidad de la lista oficial de éforos en el Arcaísmo ya desde la Antigüedad debido a una gran variedad de tradiciones simultáneas (Richer, 1998). Así pues, sobre este aspecto, siendo estrictamente rigurosos, no podemos aceptar que, al menos en el plano teórico que aquí se nos presenta, Hipócrates desoyese en dicho momento a un sabio o a alguien que tuviera un gran prestigio reconocido.

Si hay algo que trasciende de este encuentro, para nosotros con toda probabilidad ficticio (al igual que para otros, como Asheri, Lloyd y Corcella, 2007), pero historiográficamente relevante, es la animadversión que Quilón de Esparta presenta hacia una posible instauración de la tiranía en Atenas. Quizá por esta razón hay autores (Asheri, Lloyd y Corcella, 2007; Crahay, 1956; Stibbe, 1985) que han visto en esta anécdota un guiño a la condición antitiránica de este personaje, imagen que se haría popular, y que se vería reforzada más adelante con la aparición de un papiro del siglo II a. C. (Rylands $18=F G r H 105 F 1)$, en el que se describe que el propio Quilón habría llevado una lucha contra algunas tiranías durante el desempeño de su magistratura. Tras el eforado de Quilón este tipo de políticas habría continuado, lo que le habría granjeado a Esparta ya en la Antigüedad

3 Sobre Quilón y su papel en la revolución espartana, ver: Stibbe (1985) y Fornis (2016). 
su fama como pólis derrocadora de tiranos $\left(\right.$ Stibbe, 1985) ${ }^{4}$. Sin embargo, dicho carácter antitiránico está puesto en cuestión en la actualidad, ya que estas acciones contra las diferentes tiranías griegas parece que respondían más a intereses político-militares de los propios espartanos que a la defensa de regímenes políticos concretos. Se trataría, por tanto, de una propaganda del siglo $V$ que pretendía mostrar una imagen de Esparta como pólis antitiránica (Bernhardt, 1987; Thommen, 1996 y 2017; Luther 2002; Waters, 1971). A pesar de que esta imagen antitiránica fuera posterior al siglo VI, lo importante aquí es reconocer que Quilón se constituyó (falsamente) durante el clasicismo y helenismo griego como un personaje contrario a la tiranía, y no sólo para Heródoto. Quizá por ello se habría ido gestando una tradición oral que lo presentaba en Olimpia con Hipócrates. Heródoto no deja de reproducir un episodio propio de esta tradición oral, lo cual supone siempre un factor que genera muchas dudas en la actualidad, pero no tantas entonces. Quilón era para Heródoto y, seguramente, también para otros autores antiguos, el antitirano por excelencia, por eso él, y no otro, debía ser quien se encontrase con el padre de Pisístrato. De hecho, este comportamiento antitiránico en este episodio habría sido quizá una de las razones por las que seguramente, como dice Fehling (1985), Platón decidiera incluir a Quilón de Esparta en su listado de los Siete Sabios.

Lo realmente relevante de este pasaje de Heródoto es la forma en la que el historiador describe los hechos para explicar a su audiencia que la tiranía de los Pisistrátidas estaba predestinada. La inevitabilidad del destino es una idea común en la obra del de Halicarnaso y se encuentra presente también en relación al acceso al poder de otros personajes importantes, como Cípselo (Hdt. V 92), Ciro (Hdt. I 107-109) o el propio Pericles (Hdt. VI 131.2). En este sentido, Gray (1996) observa que, a diferencia de Ciro y Cípselo, el hecho de que Hipócrates desoiga los avisos de Quilón impide que en el caso de Pisístrato exista un contexto de persecución previa. También el mismo autor (Gray, 1997) ve en los calderos hirviendo sin agua elementos fantásticos tan similares a los que encontramos en las digresiones de Ciro y Cípselo, e incluso de Pérdicas (Hdt. VIII 137.3). McGlew (1993) piensa, por su parte, que estos prodigios normalmente pretendían mostrar que el tirano llegaba a serlo no tanto por ambición personal como por una cuestión de justicia con respecto a las elites de la pólis. En este caso, sin embargo, creemos que no se aplica esa idea de justicia sobre la aristocracia ateniense o al menos no queda lo suficientemente claro. Lo que sí se percibe de este episodio es el intento de Heródoto por demostrar la imposibilidad de escapar del destino, y en este caso, de la tiranía de Pisístrato, quien gozaría, además, de cierto favor divino (Lavelle, 1991; 1993; 2005). No es este un elemento exclusivo de Pisístrato, pues puede apreciarse también en el caso de otros tiranos, como el del propio Cípselo de Corinto y el oráculo de Delfos que pronosticó su nacimiento y tiranía (Hdt. V $92 \beta 2$ ), episodio que además se inserta en la obra herodotea dentro de los intentos espartanos por restaurar a Hipias unos años después de haberlo derrocado.

Hay algunos autores modernos, como Gouśchin (1999) o Lavelle (1991; 1993; 2005), que creen que detrás de este determinismo histórico de Heródoto en este episodio concreto existe una intencionalidad clara: exculpar al demos y a un génos concreto, el Alcmeónida, de la instauración de la tiranía en Atenas. Sin embargo, no podemos estar de acuerdo con esta última afirmación por varias razones. En primer lugar, porque entre los diferentes objetivos que Heródoto persigue con su obra, no está el de hacer sentir de una forma u otra, más o menos culpable por el devenir histórico a un determinado pueblo, por mucho que sus fuentes procedan de la propia Atenas como manifiestan Lavelle y otros (Masaracchia, 1998; Rhodes, 2003) -, lo cual es sólo conjetural para esta anécdota. En segundo lugar, porque Heródoto da numerosas muestras de ocasiones en las que el pueblo ateniense se deja engañar por el tirano, pero no siempre de manera inocente, sino haciéndose en cierta medida copartícipe de la instauración de la tiranía en Atenas: como cuando le conceden una guardia personal; o cuando regresa en el carro; o cuando se retiran de la batalla de

4 Sobre la fama de Esparta en la Antigüedad como pólis contraria a la tiranía, ver: Hdt. V 92.1-2; Th. I 18; Arist. Pol. 1310b-1311b; Plu. Mor. 859C-D; PIb. IV 81.13; Sch.Aeschin. II 77; FGrH 105F1. Paradiso (1995) considera que lo que sucede en el caso de Esparta tiene que ver con que la ausencia de tiranías en Esparta hacía percibir a historiadores como Tucídides que ello convertía esta pólis en defensora de la libertad. 
Palene obedeciéndole sin presentar resistencia alguna, etc. (Hdt. I 59; 60.4; 64.1). Estas muestras de apoyo por parte del demos hacia el tirano las encontramos no ya sólo en Heródoto, sino también en otros autores posteriores como Platón (Rep. 565c8-d4) o Aristóteles (Pol. 1305a1-12, 24-31) que, como observa Gouśchin (1999), aplican un enfoque mucho más racional que el de Halicarnaso omite. Heródoto tampoco parece edulcorar en ningún momento la imagen de los Alcmeónidas, ni los descarga de su responsabilidad, puesto que no sólo menciona su exilio, lo cual supone el abandono del demos a la suerte del tirano, sino que, ya antes, nos transmite hechos como el de que Megacles estaba dispuesto a otorgarle la tiranía a Pisístrato a cambio de que se casase con su hija (Hdt. I 60.2). Es el propio Megacles el que llega a un acuerdo con Pisístrato por iniciativa propia y le ayuda a orquestar el episodio del carro. Incluso Plutarco se lamenta en Sobre la malevolencia de Heródoto del nefasto trato que este historiador daba en su obra a la familia de los Alcmeónidas al tacharlos de traidores (Mor. $858 \mathrm{C}$ ), aunque no por esta alianza en concreto. No sólo nosotros, sino también Gray (1997) discrepa con Lavelle en que el relato de las tiranías de Pisístrato fuera modificado para dejar en buen lugar a los Alcmeónidas. Sin embargo, para autores modernos como Fowler (2003) las relaciones entre el de Halicarnaso y los Alcmeónidas eran buenas, valoración que creemos que no es incompatible con el tratamiento que esta familia pudiera recibir en su obra. Al fin y al cabo, como ya decía Lateiner (1989), resulta injustificable pensar en Heródoto como un propagandista de Pericles, de los Alcmeónidas o del Imperio.

Así las cosas, no da la impresión en ningún momento de que Heródoto tenga intención alguna de descargar de culpas a este génos, ni tampoco al demos. En este sentido, también debemos tener en cuenta que Heródoto no es un autor que siquiera perciba la tiranía como algo negativo per se. De hecho, creemos que la única razón por la que autores como Lavelle podrían pensar que Heródoto pretende exculpar al demos ateniense del ascenso de Pisístrato es porque desde su perspectiva moderna conciben la tiranía como un régimen negativo que imputa cierta culpa a quien la permite o facilita con su pasividad. Sin embargo, el de Halicarnaso en ningún momento de su obra se posiciona de manera lo suficientemente clara ni en contra ni a favor de este régimen político Forsdyke, 2008; Waters, 1971; contra Crahay, 1956; Davie, 1979 y Lateiner 1989) ${ }^{5}$, por lo que no hay razón alguna por la que pretendiera exculpar a nadie

Un segundo elemento histórico de este episodio sobre el que merece la pena que nos detengamos tiene que ver con el lugar en el que se encuentran el padre de Pisístrato, Hipócrates, y Quilón de Esparta. Aunque a priori resulte inocente el hecho de que ambos personajes se reúnan en Olimpia, no lo es tanto si tenemos en cuenta que durante gran parte del siglo VI, como ha mostrado Lavelle (2005), pudo haber sido un problema para los atenienses la condición de extranjeros de los Pisistrátidas. Esta familia era originaria de Pilos (Hdt. V 65.3), en la Élide, donde casualmente también se encuentra el santuario de Olimpia. Frente a otras familias como los Alcmeónidas, que Heródoto ( $V$ 72.2) se encarga de recordar que son de origen ateniense, los Pisistrátidas se muestran en anécdotas como estas como no autóctonos, algo que sin duda habría sido utilizado en su momento por sus enemigos políticos y que, en cierta medida, creemos que apuntaría a la invención (o al menos transmisión) de este episodio a la familia de los Alcmeónidas.

A partir de un estudio de este pasaje desde una perspectiva unitaria, es decir, no tanto como hecho histórico en sí, sino como relato dentro de las Historias de Heródoto, no son pocos los detalles que merecen ser comentados. La presencia de esta anécdota se explica también por el método de ring composition propio del de Halicarnaso, mediante el cual acostumbra a cerrar una digresión de una manera más o menos similar al inicio de la misma. En el caso de la tiranía de los Pisistrátidas, Esparta es el elemento de inicio y cierre de un periodo de treinta y seis años de gobierno en Atenas.

5 Reconocemos que sobre este tema existe todavía hoy bastante controversia. Asheri, Lloyd y Corcella (2007) precisan que, hacia Pisístrato por ejemplo, existen actitudes muy variadas, desde la crítica hasta la admiración. Para Sánchez-Mañas (2017) Heródoto en VI 123 estaría posicionándose contra la tiranía de los Pisistrátidas, pero creemos que el pasaje no es lo suficientemente explícito como para atribuir esta opinión al historiador. 
Quilón pronostica su advenimiento (Hdt. I 59.2-3), aunque sea mediante un episodio perfectamente prescindible, y Cleómenes le pone el punto final (Hdt. V 64-65). La propia presencia de Quilón al inicio de la digresión sobre la tiranía podría explicarse por cuestiones mnemotécnicas del propio Heródoto, que en la necesidad de recordar el desarrollo de los acontecimientos pasa en el relato de los prolegómenos de la Guerra Médica con la negativa espartana de ayudar a Creso en su insurrección contra Ciro a la visita de este a Atenas. Así, se mueve en la narración de una pólis a otra, conectando uno de los personajes más importantes de Esparta -después de una digresión previa que se remontaba hasta doscientos años-, con el padre ateniense de Pisístrato, situando la acción tan solo medio siglo antes a los hechos principales. Las recomendaciones de Quilón a Hipócrates preceden a una digresión posterior cuyos detalles Heródoto debe cuidarse de recordar: tres son los consejos que Quilón da a Hipócrates (no casarse, no tener hijos, renunciar a su hijo en caso de tenerlo), tres las facciones del Ática que continúan la narración (Hdt. I 59.3) y que ayudan a nuestro autor a explicar la situación previa a la tiranía, y también tres son las veces que Pisístrato acaba gobernando Atenas como tirano.

En definitiva, Quilón, que es para el propio Heródoto (VII 235.2) "uno de los personajes más sabios que ha habido en nuestro pueblo [el griego]", juega en este pasaje un papel doble. Desde un punto de vista unitario, conecta diferentes digresiones de la obra -los orígenes de los sistemas políticos espartano y ateniense- y facilita el desarrollo de la narración principal, la búsqueda de apoyos de Creso a mediados del siglo $\mathrm{VI}$ a. C. Pero, por otro lado, Quilón también tiene en este episodio un rol de consejero sabio, tan común en las Historias del de Halicarnaso (como el caso de Jerjes en Hdt. VII 57.1), mostrándose así como un personaje antitiránico que, en última instancia, refleja la predestinación de la tiranía de Pisístrato antes incluso de su nacimiento.

\section{Solón de Atenas}

Aunque Heródoto no lo mencione, Quilón de Esparta no habría sido el único, de acuerdo con las fuentes antiguas, en vaticinar la llegada de la tiranía a Atenas. Casualmente también habría advertido sobre la misma otro de los siete sabios de Grecia, Solón de Atenas. Son sólo dos las situaciones que se nos conservan que remitan a los momentos previos a la llegada de Pisístrato al poder previa petición de una guardia personal. Ahí radica también otra conexión entre ambos episodios aparentemente aislados.

La relación (amorosa y familiar) entre Pisístrato y Solón ha sido ampliamente expuesta no ya por la historiografía moderna, sino por las propias fuentes antiguas (sobre todo Plu. Sol. 1, 8, 10, 29-32, pero también Arist. Ath. Pol. 14.2-3, 17.2; D.S. IX 4.1, 20; Str. IX 10, etc.). Sin embargo, en el presente trabajo no pretendemos poner el foco en la misma, ni en el papel que Solón y Pisístrato jugaron con respecto a la isla de Salamina o en cualquier otra cuestión previa, sino en las fallidas advertencias que el más anciano de los Siete Sabios hizo en más de una ocasión a los atenienses sobre los peligros de la tiranía en general y de la de Pisístrato en particular, pues es de hecho en parte el poder adivinatorio de los sabios el que les granjeó después su título y fama.

Solón de Atenas es, junto a Tales de Mileto, uno de los sabios de los que más noticias se nos han conservado, y gran parte de las cuales resultan ser consecuencia directa de su relación con Pisístrato. Nombrado arconte epónimo en la Atenas del 594 (contra Miller, 1959), trató de poner fin a una delicada situación de stasis entre los aristócratas Eupátridas y el demos ${ }^{6}$. Tras haber completado su obra legislativa, Solón abandonó el Ática en principio "so pretexto de ver mundo, pero en realidad para no verse obligado a derogar ninguna de las leyes que habían promulgado" (Hdt. I 29.1), aunque no todas las versiones coinciden. Plutarco (Sol. 2.1-2), por ejemplo, consideraba que sus viajes respondían a intereses relacionados con el comercio o con adquirir nuevos conocimientos de culturas diferentes, y Aulio Gelio (XVII 21.5-7) creía que la razón por la que abandonaría Atenas

6 Sobre la vida y obra de Solón, la bibliografía es ingente. Por citar algunos ejemplos: Gilliard (1907), Masaracchia (1958), Vox (1984) y Domínguez Monedero (2001). 
se debía a que nadie había hecho caso a sus advertencias sobre las intenciones de Pisístrato. Sin embargo, la mayoría de fuentes apunta a que los viajes fueron previos a su ascenso a la tiranía.

Es Aristóteles en su Constitución de los atenienses (14.2-3) y no Heródoto, el primero que nos transmite la preocupación de Solón con respecto a las intenciones de Pisístrato de convertirse en tirano de Atenas en el momento en el que este solicitó ya una guardia personal:

Se dice que Solón, cuando Pisístrato pidió la guardia, se opuso diciendo que era más sabio que los unos y más valiente que los otros: "más sabio que cuantos no veían que Pisístrato aspiraba a la tiranía, y más valiente que los que viéndolo se callaban". Y como no convenció con sus palabras, colgó sus armas delante de su puerta y dijo que él había ayudado a la patria en cuanto había podido (pues ya era muy viejo), y que consideraba digno que los demás hiciesen también lo mismo. Solón nada consiguió entonces con sus exhortaciones: Pisístrato tomó el poder y regía los asuntos comunes más como ciudadano que como tirano?.

Una cuestión capital del presente análisis tiene que ver con explicar por qué esta oposición de Solón a Pisístrato no aparece mencionada ni en Heródoto, ni en Tucídides, ni en ninguna otra fuente previa. En el caso de Tucídides (que ni alude a la figura de Solón en su obra) o cualquier otra fuente anterior, la respuesta resulta sencilla. Solón no es un personaje que despierte un gran interés en la Atenas anterior al siglo IV.

Sin embargo, en el caso del de Halicarnaso, a pesar de ser del siglo $\mathrm{V}$ también, la ausencia de este episodio en su narración sí llama más la atención. Es cierto que Heródoto es un extranjero -tampoco es espartano y no tiene reparos en hablar de Quilón-, y que Solón no gozaba de una alta popularidad como legislador en su tiempo, pero creemos que tan sólo una construcción de este episodio a posteriori, durante el siglo IV o incluso finales del V, es capaz de explicar que dicho acontecimiento no se encuentre dentro de su obra. En primer lugar, porque comparte una misma temática histórica que el propio Heródoto reproduce a menudo en otros episodios (como el de Quilón, que ya vimos previamente, y otros tantos), en los que un personaje que hace de sabio y consejero, advierte sobre lo que considera un peligro futuro que termina haciéndose realidad (vid. supra). Las motivaciones que mueven a Heródoto a registrar algunos de estos relatos a menudo responden a su intento por plasmar que el destino es ineludible (Domínguez Monedero), por lo que en caso de haber sido conocido este episodio de Solón, habría sido susceptible de formar parte de su narración sin duda alguna. De hecho, a diferencia de Tucídides, Heródoto sí menciona a Solón en bastantes partes de su obra, entre la que cabría destacar precisamente el episodio en el que este mismo sabio vaticina el futuro desgraciado de Creso (Hdt. I 29-33) mediante una conversación que ha sido a veces vista, también, como una recreación ficticia (Boedeker, 2003; Rhodes, 2003; Fowler, 2003 la toma con escepticismo) del propio Heródoto para dejar constancia de lo que pensaba sobre el destino (Fornara, 1990; y en menor medida Immerwahr, 1954). Todos estos elementos apuntan, pues, a que probablemente Heródoto desconocía este episodio porque habría tenido un origen posterior a su época. De hecho, que Heródoto sí conozca y narre el episodio de Quilón de Esparta e Hipócrates de Atenas, el cual parece menos histórico y más lejano cronológicamente que el que aquí nos ocupa, deja patente también que no debía de existir a finales del siglo $V$ una tradición oral fuerte sobre las advertencias de Solón a la tiranía pisistrátida.

Si no existía en el siglo VI, ni en el V, ¿cuándo y cómo surgió? Parece poco probable que Aristóteles decidiera crear ex novo un episodio como el que nos transmite siendo un autor antiguo que goza de bastante buena reputación. Seguramente este filósofo decidiese recuperar esta anécdota que habría sido fruto de una larga tradición oral de la Atenas desde finales del siglo $\mathrm{V}$ o inicios del IV, que es cuando se engrandece la figura de Solón como defensor de la democracia (Mossé, 1979).

7 Esta última frase muestra para Mühl (1956, p. 318) que la fuente de la que se sirve Aristóteles procedía de una tradición amigable con el tirano ("Hier liegt uns eine ausgesprochen Peisistratosfreundliche Tradition vor"). 
Es cierto que cabe la posibilidad incluso de que sí estuviera presente, de forma oral, a mediados del siglo $\mathrm{V}$ y que el propio Heródoto decidiese no plasmarlo por escrito, el argumento ex silentio no es, a pesar de todos los elementos expuestos con anterioridad, una demostración totalmente objetiva ${ }^{8}$, pero, a la luz de todo lo argumentado, no podemos sino coincidir aquí con Stehle (2006) en que esta historia de Solón apelando al demos refleja una profecía apócrifa, producto seguramente de varios autores posteriores.

El papel de Solón como legislador es casualmente recuperado como arma de propaganda política a lo largo del siglo IV y es utilizado tanto por demócratas radicales como por moderados y oligarcas. Masaracchia (1958) y Domínguez Monedero (2001) muestran varios ejemplos en pasajes de algunos de los oradores áticos del siglo IV, como Isócrates, Demóstenes o Esquines. En ellos Solón aparece no sólo como poeta y filósofo, que también (Aeschin. III 108), sino como un buen legislador de la democracia de entonces (Isoc. VII 16; Aeschin. III 257; D. XVIII 6), patriota por su actuación con Salamina (D. XIX 252) e incluso amigo del pueblo (demotikos, en D. XVIII 6, en la misma línea que ya hizo Ar. Nu. 1187 unos años antes). Domínguez Monedero (2001, p. 120, 199) resulta bastante claro al respecto: "se recurre (...) a Solón por parte de los dos bandos principales en litigio, esto es, los oligarcas y los demócratas moderados. Pero, del mismo modo, los demócratas radicales utilizan a Solón como paradigma y modelo al que remontarse. Así pues, la lucha política en la Atenas del siglo IV va a estar marcada por estos conflictos y la recurrencia, casi obligada, a la figura de Solón”. En este sentido, de ser reales los poemas que se nos conservan de Solón, estos debieron de haber recuperado su interés social ya a finales del siglo $\mathrm{V}$ e inicios del IV, cuando su figura gana preeminencia, y no podemos aceptar por tanto una omisión deliberada de su actuación antitiránica por parte de Heródoto. Sin embargo, debemos recalcar que los poemas políticos de Solón representan en conjunto una fuerte coherencia, demasiada incluso para haber sido fruto de una vaga tradición oral que se pudiese arrastrar desde el siglo VI (Stehle, 2006), más de doscientos años antes de Aristóteles.

En medio de ese contexto del siglo IV Aristóteles defiende su figura y su obra, y la aprovecha para hacer una defensa, a su vez, de una patrios politeia que esté por encima del poder del demos. Aristóteles es, como se sabe, un importante crítico de la democracia radical del siglo IV. Pero también es contrario a la tiranía, como expresa abiertamente en su Política (1310b1-7; 1313a42-1313b25), de ahí que se decante por la opción soloniana, que considera más moderada. Con este episodio refleja que es importante hacer caso a los hombres sabios (pensamiento que le viene dado de su maestro Platón), como Solón, que no se equivocan a la hora de juzgar las intenciones de otros, a fin de evitar males mayores para todos. Recoge por escrito una tradición oral que se habría ido gestando ese mismo siglo.

La Constitución de los atenienses de Aristóteles recoge algunas de las medidas legislativas principales de la historia de Atenas desde sus orígenes hasta finales del siglo IV. A diferencia de las Historias de Heródoto, son raras las referencias a otros pueblos o a mitos pasados. Aristóteles es un autor que se mueve más en el mundo terrenal, en el plano histórico, al fin y al cabo no deja de ser un teorizador político. Por ello, no es del todo extraño que, en contraposición a Heródoto, él no nos traslade la anécdota de Quilón de Esparta y su encuentro con Hipócrates. Sin embargo, conviene atender al hecho de que este mismo episodio desaparece de toda la historiografía posterior a Heródoto. No se vuelve a mencionar en todo el período clásico. No se encuentra presente en Platón, ni en los principales oradores áticos. El único autor que la recupera es, siguiendo al propio

8 Podemos añadir otros tantos, como que, si el propio Heródoto (I 59.5) también se refiere a la petición de una guardia personal por parte de Pisístrato, ¿por qué decide omitir la oposición de Solón? Conocía algunos de sus poemas (Blaise, 2006), pero estos deberían haberle resultado a todas luces insuficientes para trasladar un episodio con la seguridad con la que lo hace Aristóteles, que sí es capaz de dotar la escena de un marco histórico (vid. infra.). De los poemas de Solón únicamente trasciende su oposición a la tiranía como régimen, no el momento en el que el personaje advierta al demos. Esto se debe a que cuando apela a alguien, Solón siempre lo hace a una audiencia localizada en un tiempo o espacio indeterminado (Stehle, 2006). 
Heródoto, Diógenes Laercio (I 68) ya en el siglo III de nuestra era.

La desaparición en las fuentes antiguas del episodio de Quilón e Hipócrates sobre los intentos del espartano de evitar la tiranía en Atenas se sucede a la par que se habría generado una tradición oral y escrita que parece querer dar dicho protagonismo a Solón. No resulta extraño que los atenienses pretendieran desentenderse del papel que algunos espartanos jugaron en relación con su propia historia local. De hecho, a estos efectos precisamente responde la digresión de Tucídides sobre el fin de la tiranía en Atenas, puesto que en su libro VI denuncia (53.3) que a pesar de lo mucho que se lo negaban, el demos sabía en el fondo que la tiranía "no había sido derribada por ellos y por Harmodio, sino por obra de los lacedemonios, y por ello vivía siempre en el temor y lo miraba todo con suspicacia". Parece existir, pues, un intento popular por sacar a Esparta de la historia de Atenas. Intento que se vería acrecentado, además, después de la Guerra del Peloponeso y de la expulsión de los Treinta Tiranos.

Así pues, la tradición literaria iría dejando atrás esta aparición de Quilón de Esparta, adoptando tan solo como verídico el episodio de Solón en Aristóteles. Algunas de estas fuentes se limitarían simplemente a reproducir la anécdota, como Cicerón (Diu. I 111; Cat. 72) o Claudio Eliano (VH VIII 16), y otras fueron añadiendo información nueva. Por ejemplo, Diodoro Sículo (IX 4.1-2, 20) matiza que Solón se presentó en el ágora con su armadura al completo intentando impedir que Pisístrato accediera a la tiranía, pero que no fue tomado en serio. La única forma de hacer que converjan ambas versiones, la de Aristóteles y la de Claudio Eliano con la de Diodoro Sículo, es que el legislador viviese cerca del ágora. En este sentido, Gilliard (1907, p. 295, n.2) vio en esta actuación de Solón más bien una representación de su manera práctica de hacer política: "revêtait bien son armure, mais, plutôt que de faire usage de ses armes, il préférait renoncer à la lutte et laisser le champ libre" a otros hombres que no fueran él. Sin embargo, esta escenificación no puede sino recordarnos a la que en su momento se vivió con respecto a la actuación de Solón cuando pretendía recuperar la isla de Salamina (Noussia-Fantuzzi, 2010), por lo que resulta complicado saber hasta qué punto deberíamos tenerla en cuenta y no se trata de un mero 'doblete' de un hecho anterior.

Filostrato (VS I 542), por su parte, cuenta incluso que Polemón habría escrito una obra al respecto de esta oposición al tirano, titulada: Solón pide la anulación de sus leyes, al obtener Pisístrato su guardia personal, la cual lamentablemente no se nos ha conservado.

Aristóteles no nos transmite nada más al margen de esta única advertencia de Solón, pero otros autores posteriores, como Plutarco, Diodoro Sículo o Diógenes Laercio, sirviéndose de los poemas que se nos habrían conservado del legislador, sí que elaboraron una narrativa en la que desarrollaban la existencia no de una, sino de varias advertencias. Lo cierto es que la interpretación que cada uno de estos autores hace de los poemas de Solón es, evidentemente, libre. Y, además, como señala Stehle (2006), es probable que algunos de ellos fueran creados ex novo con el paso del tiempo a partir de uno (o varios) inicial ${ }^{9}$. Estos tres autores de época romana emplean los poemas de Solón a voluntad, pero lo cierto es que el propio episodio que nos transmite Aristóteles podría ser ya una inferencia a partir de los mismos (o de otros autores), como especula Domínguez Monedero (2011), a quien seguimos. Así pues, para estos autores, como Diógenes Laercio (I 49) sería tras el fracaso de su primer aviso cuando Solón escribiría los siguientes versos (fr. 9D):

Un corto tiempo hará ver a los ciudadanos mi locura, la mostrará cuando la verdad se haga pública.

(Trad. modificada de la de Rodríguez Adrados)

Y después de este, otro segundo poema (fr. 10D), más extenso y mucho más conocido por

9 Coincidimos con la opinión de Lardinois $(2006$, p. 28) aquí: "I do believe that the historical Solon composed some poems -there must have been some basis for ascribing other poetry to him-, but how many (...) were actually composed by him we will never know". 
la historiografía antigua y moderna actual, que reproduce no ya sólo Diógenes Laercio (I 50) sino también con anterioridad Diodoro Sículo (IX 20.2):

De la nube emana la furia de la nieve y del granizo

y el trueno nace del brillante relámpago.

Perece una ciudad a manos de los grandes hombres porque el pueblo (demos)

en su ignorancia, cayó en la esclavitud de un tirano ( $\mu$ ovópxou).

Al que se eleva demasiado es difícil ponerle freno

después; pero es preciso desde ahora reflexionar sobre esto

(Trad. modificada de la de Rodríguez Adrados).

Los últimos dos versos de este fragmento no aparecen, sin embargo, en la obra de Diógenes Laercio, pero se nos han conservado con anterioridad (fr. 10D), por lo que sabemos que debían de existir al menos en época clásica y que no se trata, por tanto, de una invención de Diodoro Sículo. Siguiendo a Domínguez Monedero (2001) en el análisis de este poema, podemos observar cómo existe una metáfora entre los elementos de la naturaleza y la situación de la pólis. Así, la nube es un elemento que está en lo alto, sobre los demás, igual que los gobernantes lo están sobre el demos. Y de la misma forma que puede dar lluvia, regando los campos y beneficiando a todos, puede hacer lo contrario, dar granizo y nieve, perjudicándoles. $Y$ al igual que del relámpago viene el trueno, del demos puede venir el tirano (monarchos). Son claramente avisos de un Solón histórico que reflejan, al menos, un cierto miedo al futuro gobernante que pudiera aparecer en Atenas, miedo a que el poder recayera en una persona que no fuera beneficiosa para todos.

Según Diógenes Laercio (I 52), el cual parece seguir también en este caso a Diodoro Sículo (IX 20.3), una vez instaurada la tiranía, Solón compondría un último poema (fr. 8D) sobre este asunto, lamentándose ya de lo ocurrido:

Si por vuestra ineptitud sufrís ahora desgracias,

no echéis a los dioses la culpa de ellas;

pues vosotros les (тои́тоus) habéis llevado al poder al darles guardias/garantías

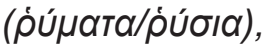

y es por esto por lo que habéis caído en penosa esclavitud.

Cada uno de vosotros anda con paso de zorra,

pero todos juntos tenéis la cabeza vacía.

Atendéis a los discursos y a las palabras de un hombre astuto,

pero no atendéis a ninguna de las cosas que suceden

(Trad. modificada de la de Rodríguez Adrados).

Este тoútous resulta complicado de saber hacia quién va dirigido. Para Domínguez Monedero (2001) podría referirse tanto a los tiranos en general, como a uno en concreto, Pisístrato, pero utilizaría el plural al referirse también a su entorno, puesto que habla de la situación como de algo que ya ha ocurrido. La idea de que Pisístrato actuaba junto a "otros" no nos resulta ajena, puesto que se ve reflejada también en un pasaje de Tucídides (VI 54.6), en donde se comenta que "siempre se cuidaban [Pisístrato e Hipias, su facción] de que uno de ellos estuviera presente en las magistraturas". Sin embargo, para otros autores, como Noussia-Fantuzzi (2010) no tiene sentido que se refiriera a Pisístrato y sus seguidores, pues en ese caso Solón habría utilizado con total

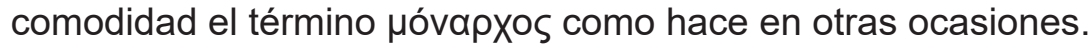

Otro de los problemas principales de este último poema lo plantea, en ese mismo verso, el término ṕúoı (garantías, represalias, recompensas, promesas), que aparece en Diógenes Laercio y parece ser más antiguo que el púpata (guardias) presente en Plutarco y Diodoro Sículo. Este hecho, convincentemente demostrado por Gottesmann (2005; y seguido por Lardinois, 2006), demostraría que la palabra púpata habría sido introducida en el texto en el mismo momento en 
el que este poema empezara a ser relacionado con Pisístrato, lo cual habría pasado, como muy pronto, en el siglo V o IV. Ello no quiere decir, como señala Lardinois (2006, p. 29) que ṕúoı fuera el término empleado originalmente, pero sí que es posible. De la misma forma en que, como dice textualmente (ibid.), "it is also possible that the poem was assigned to Solon only after it was

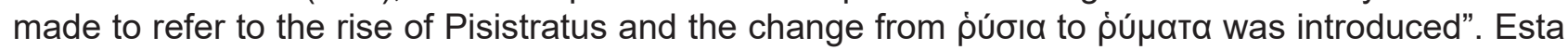
interpretación explicaría por qué Heródoto no menciona nada acerca de la actitud de Solón respecto a la petición de una guardia personal por parte de Pisístrato, porque aun conociendo los poemas, el de Halicarnaso no era capaz de vincular ninguno a dicho momento en particular.

Respecto a este mismo fr. 8D, cabe añadir que Plutarco (Sol. 30.3) reproduce, no sabemos por qué, tan sólo los últimos cuatro versos del poema. Autores como Mühl (1956), y siguiéndole Domínguez Monedero (2001), apuntan a Fanias de Éreso como la fuente de Plutarco en este pasaje 30, debido a la animadversión que se muestra hacia el tirano, a diferencia de su pasaje 31 , en donde al presentar una actitud más favorable a la tiranía estaría siguiendo a Heraclides. La falta de información, sin embargo, nos obliga tan sólo a especular en este punto.

Estos poemas son las únicas fuentes seguras que podemos atribuir a Solón, pero plantean como hemos ido viendo problemas serios relacionados, no ya con su finalidad, sino también con su propia cronología y contexto (Domínguez Monedero, 2001). Esta cuestión ha llevado a algunos autores a pensar que existen interpretaciones cronológicas erróneas, como en el caso de este tercer poema (fr. 8D), en el que Solón pudiera estar refiriéndose a Dracón y no a Pisístrato (Rihll, 1989; Anderson, 2005; Rodríguez Adrados, 1956 se muestra escéptico; contra Gottesmann, 2005). Los poemas, al fin y al cabo, se conservaron durante la Antigüedad, pero son poesías, no discursos políticos, por lo que es necesario interpretarlos con precaución, sobre todo si atendemos a la enorme cantidad de metáforas insertas en ellos, así como otras tantas figuras literarias y la falta de referencias históricas concretas, a lo que hay que añadir, además, la posibilidad de que algunos fueran creaciones de la propia época clásica (Stehle, 2006). Asimismo, cabe recordar que tan sólo se ha conservado un $6 \%$ de la producción total (Domínguez Monedero, 2001). En este caso en concreto nosotros sí coincidimos con Masaracchia (1958) y Domínguez Monedero (2001) en que en este último poema nuestro pseudo-Solón, sí se estaría refiriendo a una tiranía ya establecida en Atenas. Aunque ello no quiere decir, como señalábamos con anterioridad, que este poema pueda remitirse con seguridad al siglo VI y al propio Solón, puesto que las dudas planteadas con respecto al uso del término jujata nos hacen pensar que se trata más bien de un poema (re)construido en el período clásico. Sin embargo, subyace una cierta preocupación histórica por parte de Solón acerca de lo que pudiera ocurrir en la pólis. En los vv. 1-2 se aprecia cómo apela a alguien (el demos historiográficamente, su propia facción quizá históricamente) para decir que la culpa de lo sucedido no la tienen los dioses sino su ineptitud (aunque reconoce en el v. 5 la inteligencia de cada uno de ellos por separado). Los dos últimos versos también parecen apuntar a una construcción a posteriori que pretende insertar en este poema un contexto pisistrátida y no draconiano, puesto que de Pisístrato las fuentes clásicas cuentan que era un hombre astuto e inteligente (narran cómo Pisístrato engañaba al demos con facilidad, ya fuera solicitando una guardia o a través de la treta del carro, y a Megacles con el casamiento de su hija; episodios profusamente narrados en Hdt. I 59-63 y Arist. Ath. Pol. 14-19, vid. supra), así como un grandísimo orador (atendéis a los discursos y a las palabras; AP Anon. XI 442; Cic. Orat. III 137; Val.Max. VIII 9 ext. 1-2; D.Chr. XXII 1).

Algunos autores (Val. Max. V 3 ext. 2; Plu. Sol. 29.5 y Comp. Sol. Publ. 26 [3]) olvidaron por completo el episodio de Quilón de Esparta narrado por Heródoto, no sólo por no escribirlo, sino porque manifestaban abiertamente que Solón había sido el primero en vaticinar la tiranía en Atenas y en percatarse de las intenciones de Pisístrato. Queda abierta la interpretación de si realmente conocían el pasaje de Heródoto y no lo mencionaban por cuestionar su historicidad (lo que no parece probable, puesto que no plantean sus dudas al respecto de manera explícita) o si, más bien, prefirieron no aludirlo adrede, con el fin de dotar de un mayor protagonismo y carácter antitiránico a Solón (Vox, 1984; Gouśchin, 1999), como es el caso de Plutarco y su Vida de Solón, que para Mossé $(1979 ; 1996)$ estaría fuertemente influenciada por la escuela de Aristóteles. 
Los últimos años de la vida de Solón se muestran igual de confusos en las fuentes antiguas. Para Valerio Máximo (V ext. 3.2), Dion Crisóstomo (XXXVII 4) y Aulo Gelio (NA XVII 21.4) y un fragmento de los papiros de Oxirrinco (4.664), este se habría exiliado (sin unanimidad entre si fue a Chipre o Corinto), bien por la instauración de la tiranía, bien porque no le hacían caso en sus avisos sobre las intenciones de Pisístrato. Según Plutarco, sin embargo, la relación entre Pisístrato y Solón no se mantendría tensa durante mucho tiempo. De acuerdo con el de Queronea (Sol. 31.2), ambos personajes terminarían reconciliándose e incluso Solón acabaría siendo su consejero, interpretación esta que parece tener su origen en los biógrafos helenísticos, pues Aristóteles presenta un Solón diametralmente opuesto a la tiranía, lo común en el siglo IV (Noussia-Fantuzzi, 2010). Ambas versiones, tanto la del posible regreso como la del exilio forzoso, difieren en parte de la de Diógenes Laercio (I 53-54, 66-67), quien si bien refleja una cierta distensión entre ambos reproduciendo un intercambio epistolar, con toda probabilidad espurio, mediante el cual Pisístrato le comunica a Solón que regrese a Atenas y que no habrá consecuencias, termina narrando a su vez la negativa del arconte de volver a su patria aun reconociendo a Pisístrato como "el mejor de todos los tiranos". En este sentido, da la impresión, pues, de que Diógenes Laercio mezcla los viajes de Solón y su posible exilio en Creta (I 133).

Asimismo, no menos controvertidos resultan los testimonios que se nos han conservado sobre la muerte de Solón, lo cual vuelve a poner de manifiesto la precaución que debemos tener al analizar sus últimos años de vida y su relación con Pisístrato y los primeros momentos de la tiranía ateniense. De hecho, el mismo Plutarco (Sol. 32.2; y en parte P. Oxy. 4.664) reconoce aquí explícitamente sus dudas, por un lado, en cuanto a los años que vivió, al manifestar que existen versiones dispares, como la de Heráclides del Ponto, para quien duró bastante tiempo después de la instauración del nuevo régimen, y la de Fanias de Éreso, que habría defendido su fallecimiento apenas dos años después; y, por otro lado, respecto a su funeral y enterramiento. Así, de acuerdo también con Plutarco (Sol. 32.3) "su cadáver fue quemado y sus cenizas diseminadas por la isla de Salamina", lo que le resulta "a juzgar por lo insólito de la noticia, de todo punto increíble y fabuloso pero así se ha escrito por muchos autores de prestigio y entre ellos por Aristóteles el filósofo" (fr. 392 Rose $_{2}$; otra versión también en D.L. I 62). Afirmación esta última que, por supuesto, también tiene su contestación en otras fuentes, como Claudio Eliano (VH VIII 16), quien sí defiende la vuelta de Solón a Atenas y afirma que habría sido enterrado cerca de la muralla poco después de su regreso (coincidiendo con Fanias de Éreso y contradiciendo así a quienes dicen que murió en el exilio). Añade como prueba de ello que el respeto de Pisístrato hacia él era tal que incluso "en el ágora levantaron una estatua de bronce en su honor y le otorgaron un funeral público junto a las puertas de la muralla", escultura de la que tenemos constancia ya en las fuentes desde el siglo IV a. C. (D. XXVI 23) y que todavía se conservaba en el siglo II d. C. (Paus. I 16.1). Sin embargo, cabe recordar que no sería la única, puesto que al parecer también habría otra en el ágora de Salamina (Aeschin. I 25; D. XIX 251 refleja problemas de cronología).

Como puede desprenderse de todo este conjunto de testimonios, la línea que separa el Solón histórico y el Solón legendario parece que se va difuminando con el paso del tiempo. Los diferentes autores de época romana muestran versiones a menudo contradictorias fruto de una mitificación del primer sabio de todos, lo que repercute, a su vez, en la prudencia que debemos tener a la hora de analizar la relación que habría existido entre Pisístrato y Solón al final de la vida de este, así como la posible historicidad de algunos episodios como el principal aquí abordado. Lo único que parece claro es que Pisístrato debía de sentir un profundo respeto por Solón y por sus leyes, que no modificó durante toda su tiranía (Hdt. I 59.6; Th. VI 54.6; Plu. Sol. 31.3 matiza que mantuvo la mayoría; D.L. I 53) $)^{10}$, y también que pudo haber sido el impulsor de la erección de una estatua en reconocimiento por su labor. Ahora bien, hasta qué punto pretendía ganarse el favor de Solón durante los primeros años de su gobierno mientras estaba vivo y no tanto captar sus apoyos

10 En la realidad, resulta complicado discernir qué leyes sí se pueden atribuir a Solón y cuáles no (cf. Mossé 1979). 
y su memoria una vez hubo fallecido, es una cuestión que desgraciadamente queda en el aire.

\section{Reflexiones finales}

A la vista de todo lo expuesto, nos encontramos ante dos formas de entender los augurios sobre el advenimiento de la tiranía de los Pisistrátidas por parte de los Sabios. La historiografía griega transmite estos episodios, que creemos construidos a posteriori, en los que dos de los Siete Sabios de Grecia trataron de impedir que Pisístrato se convirtiera en tirano. Por un lado, está el aviso de Quilón, que reproducen tan sólo Heródoto y Diógenes Laercio, y por otro lado las protestas abiertas de Solón, ampliamente recogidas por la historiografía del siglo IV en adelante. Aunque aparentemente dichos episodios sean de naturaleza diferente, en el sentido de que uno pertenezca más al campo religioso y otro al político y asambleario, la base de ambos es la misma: son sabios que aciertan en sus vaticinios sobre Pisístrato. Adivinan lo que va a suceder, haya o no elementos religiosos de mayor o menor calado. Al fin y al cabo, la política y la religión se entremezclan con facilidad en la Antigüedad, no se sigue la taxonomía actual, por lo que la relación entre ambos radica principalmente en la certeza de Quilón primero, y de Solón después, sobre lo que iba a suceder. La clave de la conexión entre estos testimonios radica además, como se ha visto, en la falta de coincidencia temporal entre ambos, cuando el episodio de Quilón deja de aparecer en las fuentes es cuando surge el de Solón.

El augurio de Quilón en Heródoto responde a motivaciones internas del propio autor, de Heródoto, quien pretende reflejar su postura sobre los vaticinios y sobre el devenir histórico como hecho inevitable, sin ánimo alguno de excusar al demos de la instauración de la tiranía, como han querido ver otros autores. Estos prodigios, de hecho, se aprecian también dentro del relato herodoteo en otros momentos de la tiranía de los Pisistrátidas, no sólo en su inicio, como en el caso del sueño premonitorio de la muerte de Hiparco (V 56) o en la visión de Hipias en Maratón (VI 107). Asimismo, la presencia de este episodio en la obra de Heródoto tiene que ver con la propia unidad literaria de su obra, en la que Esparta se constituye como un nexo de unión entre las diferentes digresiones del de Halicarnaso. En el caso de los avisos de Solón, será Aristóteles el primero en hablarnos de los mismos. Este Solón, como sujeto político contrario a Pisístrato, proporcionaría a los atenienses del siglo IV un referente local contrario a la tiranía en un momento de la historia de Atenas en que su figura empieza a ser reivindicada más como legislador y padre de la democracia ateniense que como sabio (Arist. Pol. 1274a1-5 o Isoc. VII 16 en la primera mitad del siglo, son ejemplos de ello). Su oposición a la tiranía habría sido en cierta medida histórica (Lardinois, 2006; Harris, 2006; Noussia-Fantuzzi, 2010 se refiere a su miedo a otros líderes poderosos), pero su oposición directa a la guardia de Pisístrato tan solo podemos considerarla literaria.

En la historiografía dos de los Siete Sabios de Grecia dieron aviso de que Pisístrato pretendía convertirse en tirano. Ambas advertencias fueron desoídas, la primera por Hipócrates, el padre del futuro tirano, y la otra por el demos, que sólo pensaba en su interés particular ("Cada uno de vosotros anda con paso de zorra, pero todos juntos tenéis la cabeza vacía", diría Solón en uno de sus poemas). Es así como en la memoria de los atenienses Pisístrato consiguió sobreponerse, actuando como un tirano astuto, inteligente y hábil, un orador que era capaz de cautivar con sus palabras y discursos más que cualquier otro miembro de la elite ateniense. Puede ser, pues, en última instancia, que esta fuera una de las razones por las que hubo autores que incluso decidieron incluir a Pisístrato de Atenas entre este selecto grupo de sabios, aun habiendo sido un tirano (D.L. I 13).

\section{Bibliografía}

Anderson, G. (2005). Before turannoi were tyrants: rethinking a chapter of early Greek history. Classical Antiquity, 24 (2), 173-222.

Asheri, D., Lloyd, A., Corcella, A. (2007). A Commentary on Herodotus Books I-IV. Oxford: Oxford 
University Press.

Bernhardt, R. (1987). Die Entstehung der Legende von der tyrannenfeindlichen Außenpolitik Spartas imsechsten und fünften Jahrhundert v. Chr. Historia, 36 (3), 257-289.

Blaise, F. (2006). Poetics and politics: tradition re-worked in Solon's 'Eunomia' (Poem 4). En Blok, J. H. y Lardinois, A. P. M. H. (eds.), Solon of Athens. New historical and philological approaches (pp. 114-133). Leiden-Boston: Brill.

Boedeker, D. (2003). Pedestrian Fatalities: The Prosaics of Death in Herodotus. En Derow, P. y Parker, R. (eds.), Herodotus and his World. Essays from a Conference in Memory of George Forrest (pp. 17-36). Oxford: Oxford University Press.

Crahay, R. (1956). La littérature oraculaire chez Hérodote. Paris: Les Belles Lettres.

Davie, J. H. (1979). Herodotus and Aristophanes on Monarchy. Greece \& Rome, 26 (2), 160-168.

Domínguez Monedero, A. J. (1997). El tirano y el juicio de la posteridad. En Presedo, F. J., Guinea, P., Cortés, J. M., y Urías, R. (eds.), Xaĩpe. II Reunión de historiadores del mundo griego antiguo. Homenaje al Profesor Fernando Gascó (pp. 329-346). Sevilla: Sevilla Scriptorium.

Domínguez Monedero, A. J. (2001). Solón de Atenas. Barcelona: Crítica.

Fehling,D.(1985). Diesieben Weisenund diefrühgriechische Chronologie. Einetraditionsgeschichtliche Studie. Bern-Frankurt-New York: Peter Lang.

Fornara, C. W. (1990). Human History and the Constraint of Fate in Herodotus. En Allison, J. W. (ed.), Conflict, antithesis and the Ancient Historian (pp. 25-45). Columbus: Ohio State University Press.

Fornis, C. (2016). Esparta. La historia, el cosmos y la leyenda de los antiguos espartanos. Sevilla: Universidad de Sevilla.

Forsdyke, S. (2008). Herodotus, political history and political thought. En Dewald, C. y Marincola, J. (eds.), The Cambridge Companion to Herodotus (pp. 224-241). Cambridge University Press.

Fowler, R. (2003). Herodotos and Athens. En Derow, P. y Parker, R. (eds.), Herodotus and his World. Essays from a Conference in Memory of George Forrest (pp. 305-317). Oxford: Oxford University Press.

Gilliard, C. (1907). Quelques réformes de Solon. Essai de critique historique. Lausanne: Imprimerie Georges Bridel \& Cie.

Gottesmann, A. (2005). Two Notes on Solon Fr. 11W. Mnemosyne, 58 (3), 412-415.

Gouschin, V. (1999). Pisistratus' Leadership in A. P. 13. 4. and the Establishment of the Tyranny of 561/60 B. C. Classical Quarterly, 49 (1), 14-23.

Gray, V. J. (1996). Herodotus and Images of Tyranny: The Tyrants of Corinth. The American Journal of Philology, 117 (3), 361-389.

Gray, V. J. (1997). Reading the rise of Pisistratus: Herodotus 1.56-68. Histos, 1, 128-153.

Immerwahr, H. R. (1954). Historical action in Herodotus. Transactions and Proceedings of the American Philological Association, 85, 16-45.

Harris, E. M. (2006). Solon and the spirit of the laws in archaic and classical Greece. En Blok, J. H. y Lardinois, A. P. M. H. (eds.), Solon of Athens. New historical and philological approaches (pp. 290-318). Leiden-Boston: Brill.

Lardinois, A. P. M. H. (2006). Have we Solon's verses? En Blok, J. H. y Lardinois, A. P. M. H. (eds.), Solon of Athens. New historical and philological approaches (pp. 15-35). Leiden-Boston: Brill.

Lateiner, D. (1989). The Historical Method of Herodotus. Toronto-Buffalo-London: University of Toronto Press.

Lavelle, B. M. (1991). The Compleat Angler: Observations on the Rise of Peisistratos in Herodotos (1.59-64). Classical Quarterly, 41 (2), 317-324.

Lavelle, B. M. (1993). The Sorrow and the Pity. A Prolegomenon to a History of Athens under the Peisistratids, c. 560-510 B.C., Historia Einz. 80. Stuttgart: Franz Steiner.

Lavelle, B. M. (2005). Fame, Money and Power. The Rise of Peisistratos and "Democratic" Tyranny at Athens. Ann Arbor: University of Michigan Press.

Luther, A. (2002). Chilon von Sparta. En Goltz, A., Luther, A. y Schlange-Schöningen, H. (eds.), 
Gelehrte in der Antike. Alexander Demandt zum 65. Geburstag (pp. 1-16). Colonia-WeimarWienn: Böhlau.

Masaracchia, A. (1958). Solone. Firenze: La Nuova Italia Editrice.

Masaracchia, A. (1998). Riflessioni sull'antico. Studi sulla cultura greca. Pisa-Roma: Istituti editoriali e poligrafici internazionali.

McGlew, J. F. (1993). Tyranny and political culture in Ancient Greece. Ithaca-London: Cornell University Press.

Miller, M. (1959). The earlier Persian dates in Herodotus. Klio, 37, 29-52.

Mossé, C. (1979). Comment s'élabore un mythe politique: Solon, «père foundateur» de la démocratie athénienne. Annales. Économies, Societés, Civilisations, 34 (3), 425-437.

Mossé, C. (1996). Due miti politici: Licurgo e Solone. En Settis, S. (ed.), I Greci. Storia Cultura Arte Società. 2. Una storia greca. 1. Formazione (pp. 1325-1335). Torino: Einaudi.

Mühl, M. (1956). Solon gegen Peisistratos. Ein Beitrag zur peripatetischen Geschichtschreibung. Rheinisches Museum, 99, 315-323.

Nafissi, M. (1991). La nascita del kosmos. Studi sulla storia e la società di Sparta. Napoli: Edizioni Scientifiche Italiane.

Noussia-Fantuzzi, M. (2010). Solon the Athenian, the Poetic Fragments. Leiden-Boston: Brill.

Paradiso, A. (1995). Tempo della tradizione, tempo dello storcio: Thuc. I. 18 e la storia arcaica spartana. Storia della storiografia, 28, 35-45.

Rhill, T. E. (1989). Lawgivers and Tyrants (Solon, Frr. 9-11 West). Classical Quarterly, 39 (2), 277286.

Rhodes, P. J. (2003). Herodotean Chronology Revisited. En Derow, P. y Parker, R. (eds.), Herodotus and his World. Essays from a Conference in Memory of George Forrest (pp. 58-72). Oxford: Oxford University Press.

Richer, N. (1998). Les éphores. Études sur l'histoire et sur l'image de Sparte (VIII - III siècles avant J.-C.). Paris: Publications de la Sorbonne.

Rodríguez Adrados, F. (1956). Líricos griegos. Elegíacos y yambógrafos arcaicos (siglos VII - V a. C.). Barcelona: Alma Máter.

Sánchez Mañas, C. (2017). Los oráculos en Heródoto. Tipología, estructura y función narrativa. Zaragoza: Prensas de la Universidad de Zaragoza.

Stehle, E. (2006). Solon's self-reflexive political persona and its audience. En Blok, J. H. y Lardinois, A. P. M. H. (eds.), Solon of Athens. New historical and philological approaches (pp. 79-113). Leiden-Boston: Brill.

Stibbe, C. M. (1985). Chilon of Sparta. Meded, 46, 7-24.

Thommen, L. (1996). Lakedaimonion Politeia: Die Entstehung Der Spartanischen Verfassung, Historia Einz. 103. Stuttgart: Franz Steiner.

Thommen, L. (2017). Sparta. Verfassungs- und Sozialgeschichte einer griechischen Polis. Stuttgart: Metzler.

Vox, O. (1984). Solone autoritratto. Padova: Editrice Antenore.

Waters, K. H. (1971). Herodotos on Tyrants and Despots. A Study in Objectivity. Historia Einz. 15. Wiesbaden: Franz Steiner.

\section{Fuentes}

AA.VV. Antología Palatina. (Epigramas helenísticos). Madrid: Editorial Gredos. 1978. [Edición de Manuel Fernández-Galiano].

Aristófanes. Comedias II. Las nubes, las avisas, la paz, los pájaros. Madrid: Editorial Gredos. 2007. [Edición de Luis M. Macía Aparicio].

Aristóteles. Constitución de los atenienses. Madrid: Editorial Gredos. 1984. [Edición de Manuela García Valdés].

Aristóteles. Política. Madrid: Editorial Gredos. 1988. [Edición de Manuela García Valdés]. 
Aulo Gelio. Noches áticas II. Libros 11-20. León: Universidad de León. 2006. [Edición de ManuelAntonio Marcos Casquero y Avelino Domínguez García].

Cicerón. Sobre el orador. Madrid: Editorial Gredos. 2002. [Edición de José Javier Iso].

Cicerón. Sobre la divinación. Sobre el destino. Timeo. Madrid: Editorial Gredos. 1999. [Edición de Ángel Escobar].

Cicerón. Sobre la vejez. Madrid: Editorial Tal vez, Colección Clásicos. 2001. [Edición de Rosario Delicado Méndez].

Claudio Eliano. Historias curiosas. Madrid: Editorial Gredos. 2006. [Edición de Juan Manuel Cortés Copete].

Demóstenes. Discursos políticos I. Madrid: Editorial Gredos. 1980. [Edición de Antonio López Eire]. Demóstenes. Discursos políticos II. Madrid: Editorial Gredos. 1985. [Edición de Antonio López Eire]. Diodoro Sículo. Biblioteca Histórica. Libros IX-II. Madrid: Editorial Gredos. 2006. [Edición de Juan José Torres Esbarranch].

Diógenes Laercio. Vidas de los filósofos ilustres. Madrid: Alianza. 2011. [Edición de Carlos García Gual].

Dión de Prusa. Discursos. XII-XXXV. Madrid: Editorial Gredos. 1989. [Edición de Gonzalo del Cerro Calderón].

Esquines. Discursos. Testimonios y cartas. Madrid: Editorial Gredos. 2002. [Edición de José María Lucas de Dios]

Estrabón. Geografía. Libros VIII-X. Madrid: Editorial Gredos. 2008. [Edición de Juan José Torres Esbarranch].

Filóstrato. Vidas de los sofistas. Madrid: Editorial Gredos. 1999. [Edición de María Concepción Giner Soria].

Heródoto. Historia. Libro I. Clío. Madrid: Editorial Gredos. 1992. [Edición de Francisco R. Adrados y Carlos Schrader].

Heródoto. Historia. Libros V-VI. Madrid: Editorial Gredos. 1981. [Edición de Carlos Schrader].

Heródoto. Historia. Libro VII. Polimnia. Madrid: Editorial Gredos. 1985. [Edición de Carlos Schrader].

Isócrates. Discursos. Madrid: Editorial Gredos. 1982. [Edición de Juan Signes Codoñer y Juan Manuel Guzmán Hermida].

The Oxyrhynchus Papyri. Part IV. Oxford: Horace Hart. 1904. [Edición de Bernard Grenfell y Arthur Hunt].

Pausanias. Descripción de Grecia. Libros I-II. Madrid: Editorial Gredos. 1994. [Edición de María Cruz Herrero Ingelmo].

Platón. Diálogos I. Apología, Critón, Eutifrón, Ion, Lisis, Cármides, Hipias menor, Hipias mayor, Laques, Protágoras. Madrid: Editorial Gredos. 1981. [Edición de Emilio Lledó Íñigo, Julio Calonge Ruiz y Carlos García Gual].

Platón. Diálogos IV. República. Madrid: Editorial Gredos. 1986. [Edición de Conrado Eggers Lan].

Plutarco. Vidas paralelas. I. Teseo-Rómulo, Licurgo-Numa. Madrid: Editorial Gredos. 1985. [Edición de Aurelio Pérez Jiménez].

Plutarco. Obras morales y de costumbres. (Moralia) IX. Madrid: Editorial Gredos. 2002. [Edición de Vicente Ramón Palerm y Jorge Bergua Cavero].

Plutarco. Vidas paralelas. II. Solón-Publícola, Temístocles-Camilo, Perícles-Fabio Máximo. Madrid: Editorial Gredos. 2008. [Edición de Aurelio Pérez Jiménez].

Polibio. Historias. Libros I-IV. Madrid: Editorial Gredos. 1981. [Edición de Alberto Díaz Tejera y Manuel Balasch Recort].

Tucídides. Historia de la Guerra del Peloponeso. Libros I-II. Madrid: Editorial Gredos. 1990. [Edición de Julio Calonge Ruíz y Juan José Torres Esbarranch].

Tucídides. Historia de la Guerra del Peloponeso. Libros V-VI. Madrid: Editorial Gredos. 1992. [Edición de Juan José Torres Esbarranch].

Valerio Máximo. Hechos y dichos memorables. Libros VII-IX. Epítomes. Madrid: Editorial Gredos. 2003. [Edición de Santiago López Moreda, María Luisa Harto Trujillo y Joaquín Villalba Álvarez]. 



\section{Panta Rei}

PANTA REI es una revista digital de investigación orientada a la Historia y otras ciencias afines. Su principal objetivo es la transmisión del conocimiento científico, dando una oportunidad también a los jóvenes investigadores que quieren abrirse camino en el estudio de las ciencias humanas y sociales. Se compone de estudios originales relacionados con la disciplina histórica así como su didáctica y difusión. Las diferentes secciones que componen la revista son: artículos de investigación, entrevistas a profesionales, recensiones de monografías de actualidad y crónicas de congresos o eventos científicos relevantes.

Todos los artículos publicados son objeto de un proceso de revisión a cargo de un mínimo de dos evaluadores, que se consideran expertos en el ámbito temático del artículo propuesto. Nuestro deseo es poder ofrecer unos contenidos rigurosos, de calidad y de interés.

EI CEPOAT (Centro de Estudios del Próximo Oriente y la Antigüedad Tardía de la Universidad de Murcia) es la institución encargada de la coordinación y gestión de la revista, desde donde anualmente se lanzará la convocatoria para aquellos que estén interesados en publicar sus trabajos, siempre relacionados con la Historia, Arqueología, Historia del Arte, Didáctica de la Historia, etc.

PANTA REI is a digital journal focused on History and other sciences related to it. Its main objective is the transmission of scientific knowledge by giving also an opportunity to young researchers who want to make their way in the study of human and social sciences. It is composed by original studies related to History, as well as its didactics and promotion. The different sections of this journal are: research articles, interviews to professionals, recensions on monographs about current issues and reports about congresses or relevant scientific events.

All the articles published are subject to a revision process carried out by a minimum of two reviewers who are considered to be experts in the field of the article proposed. Our wish is to offer rigorous contents with quality and being of interest to the reader.

CEPOAT (Centre of Studies of the Middle East and Late Antiquity of the University of Murcia) is the institution in charge of the coordination and management of this journal. This is the centre from where the call for papers will be launched for all the people interested in publishing their papers, always related to History, Archeology, Art History, Teaching History, etc. 


\section{Normas de Publicación}

El autor se compromete a enviar trabajos originales, que no se encuentren publicados en otras revistas ni en otros idiomas. Así mismo, el mismo artículo no podrá ser presentado en otras revistas mientras dure el proceso de evaluación.

\section{Envío y presentación de originales}

Los artículos se enviarán exclusivamente a través del correo electrónico a la dirección pantarei@um.es. Los textos serán enviados en formato DOC y las imágenes en formato JPEG o TIFF, y con un tamaño mínimo de 2000 px. Éstas no aparecerán incorporadas en el texto, sino enviadas en archivo aparte y correctamente numeradas según su posición en el texto. Junto al trabajo, se rellenará y enviará un documento aparte en el que se especifiquen los datos del autor siguiendo el modelo disponible en la página Web de la revista.

Para la redacción de los trabajos se tendrá en cuenta el Manual de la American Psychological Association, en su sexta edición. La extensión máxima de los trabajos será de 30 páginas. La tipografía será Arial 11, con interlineado sencillo y sin espacio alguno entre párrafos. El texto deberá ir justificado a ambos márgenes y sin sangría en los primeros párrafos. Los márgenes serán de $2,50 \mathrm{~cm}$. En los casos en los que fuera necesario incorporar notas, éstas irán a pie de página, enumeradas consecutivamente, con tipografía Arial 10, interlineado sencillo y justificadas a ambos márgenes.

Una información más detallada se encuentra disponible en la página http://www.um.es/cepoat/ pantarei.

\section{Proceso de valoración y evaluación}

Una vez recibidos los trabajos, la Revista realizará una primera valoración. Si el trabajo enviado se ajusta a las normas de presentación propuestas, la temática es coincidente con la línea editorial de la revista y posee la calidad científica necesaria, será remitido al consejo asesor para una primera evaluación. Si no es así en este primer paso se puede rechazar directamente los documentos que incumplan claramente la línea editorial.

Será el Consejo Asesor quien indique a la revista la originalidad, relevancia, estructura, redacción, aparato bibliográfico, etc. del trabajo enviado y, para ello, se designará a dos revisores expertos externos que evaluarán cada uno de los trabajos, que pueden formar parte (o no) de este Consejo Asesor. La selección de los revisores se ajustará a la temática y características metodológicas del trabajo. El nombre y filiación de los autores serán eliminados del trabajo para su revisión, así como los revisores actuarán de manera anónima y confidencial.

Los revisores deberán rellenar un informe de evaluación que centrará su atención en aspectos tales como características formales, originalidad y novedad de los trabajos, relevancia de las propuestas y los resultados, calidad metodológica y validez científica.

Una vez terminado el proceso se decidirá la aceptación o no de los mismos y su publicación en el número que sea pertinente, así como las modificaciones susceptibles de ser realizadas para su final publicación. Dicha notificación se enviará únicamente por correo electrónico, en un plazo máximo de seis meses. 


\section{Publishing rules}

The author is committed to submit original papers not having been published in other reviews or in other languages. In this way, it is not allowed for the same paper to be presented in other reviews during the evaluation process.

\section{Submission and presentation of originals}

The articles will be exclusively submitted by email to pantarei@um.es. The texts will be submitted in DOC format and the images in JPEG or TIFF format, and with a minimum size of 2000 px. Images will not be integrated in the text but sent in another file and properly numbered according to their position in the text. Attached to the paper, a document will be filled out and sent where the author's data will be specified following the model available on the website.

The sixth edition of the Manual of the American Psychological Association will be taken into account for the writing of the papers. The length of the papers must not exceed 30 pages. Typography will be Arial 11 , with simple line spacing and no space between paragraphs. The text must be justified on both margins without indentation in the first paragraphs. Margins size will be $2.50 \mathrm{~cm}$. Where it could be necessary the incorporation of notes, they will be at the bottom of the page, consecutively numbered with typography Arial 10, simple line spacing and justified on both margins.

More detailed information is available on the website: http://www.um.es/cepoat/pantarei.

\section{Examination and assessment process}

The Journal will submit the papers to a first examination once received. If the paper follows the presentation guidelines, the subject agrees with the editorial line of this journal, and possess the scientific quality required, it will be sent to the advisory council for a first assessment. If not, the documents which clearly fail to complete the editorial line may be rejected straightaway in this first step.

The Advisory Council will indicate the originality, relevance, structure, writing, bibliography, etc. of the text to the journal; for this purpose, two outside experts will be designated to review the papers; these experts can be (or not) part of this Advisory Council. The selection of the experts will adjust to the subject and methodological characteristics of the paper. Name and affiliation of the author will be eliminated from the text for its review, in this way experts will act anonymously and confidentially.

The experts will fill out an assessment report which will focus on aspects such as formal characteristics, originality and novelty of the papers, relevance and results of the proposal, methodological quality and scientific validity.

Once the process is finished, the acceptance or not of the papers and its publication in the corresponding edition will be decided, as well as the modifications that may be done for its final publication. This notification will be sent by email within 6 months maximum. 


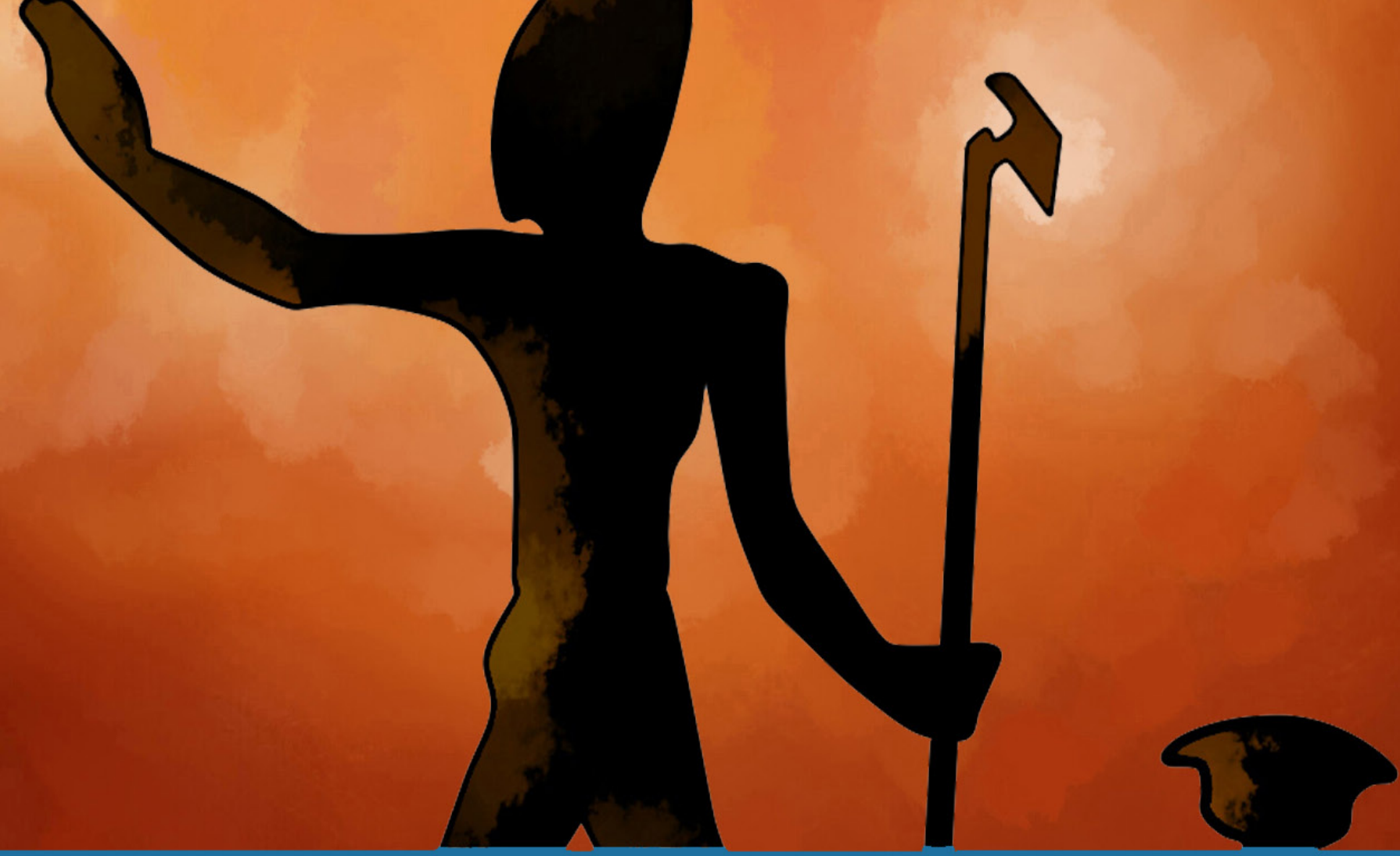

GepOA

centro de estudios de

próximo oriente y la

antigüedad tardía 